AperTO - Archivio Istituzionale Open Access dell'Università di Torino

\title{
A direct time-based ITC approach for substrate turnover measurements demonstrated on human FMO3
}

This is a pre print version of the following article:

Original Citation:

Availability:

This version is available http://hdl.handle.net/2318/1703986

since 2019-06-05T12:41:14Z

Published version:

DOI:10.1039/C9CC01356C

Terms of use:

Open Access

Anyone can freely access the full text of works made available as "Open Access". Works made available under a Creative Commons license can be used according to the terms and conditions of said license. Use of all other works requires consent of the right holder (author or publisher) if not exempted from copyright protection by the applicable law. 


\section{IIIS AperTO}

UNIVERSITÀ

DEGLI STUDI

DI TORINO

This is the author's final version of the contribution published as:

[Gianluca Cautucci, Sheila J. Sadeghi, Gianfranco Gilardi, Direct time-based ITC for substrate urnover measurement demonstrated on human FMO3, Chemical Communications, 55, 2019, pagg. 6217-6220, DOI: 10.1039/c9cc01356c]

The publisher's version is available at:

[https://pubs.rsc.org/en/content/articlepdf/2019/cc/c9cc01356c]

When citing, please refer to the published version.

Link to this full text:

[https://pubs.rsc.org/en/content/articlepdf/2019/cc/c9cc01356c] 
Received 00th January 20xx, Accepted 00th January 20xx

DOI: $10.1039 / \mathrm{x} 0 \mathrm{xx} 00000 \mathrm{x}$

\section{Direct time-based ITC approach for substrate turnover measurement demonstrated on human FMO3}

Gianluca Catuccia, Sheila J. Sadeghia and Gianfranco Gilardia* 
Transient binding EVENTS ARE a CHALLENGING ISSUE IN ENZYMOLOGY. HeRE WE DEMOSTRATE A TIME-BASED ITC APPROACH TO HUMAN FLAVIN-CONTAINING MONOOXYGENASE 3, AN IMPORTANT DRUG METABOLISING ENZYME. We MEASURE KINETIC CONSTANTS AND WE DEMONSTRATE HOW THIS APPROACH CAN BE EXPLOITED FOR MEASURING THE INHIBITON OF THE CONVERSION OF THE KEY SUBSTRATE TRIMETHYLAMINE TO TRIMETHYLAMINE N-OXIDE.

Enzymes offer the possibility to study the details of the protein-ligand interaction using a variety of techniques among which X-ray diffraction, nuclear magnetic resonance, surface plasmon resonance, fluorescence and isothermal titration calorimetry ${ }^{1}$. In some cases ligand binding is transient and this can hamper the measurements of detailed thermodynamic and kinetic parameters that are crucial for understanding the phenomenon. Here we report an advanced calorimetric approach for the identification of enzyme-ligand interactions in short-lived complexes. In order to demonstrate its applicability, we have used the recombinant human flavin-containing monooxygenase 3 (hFMO3) as test-case. The reaction mechanism of hFMO3 involves the reduction by NADPH and the formation of a hydroperoxy intermediate FAD that can perform a nucleophilic attack on the target substrate acting like a "loaded gun"2,3. This involves a short-lived binding of the substrate to the enzyme only for the time required by FMO3 to oxidize a large number of $\mathrm{N}$ - or $\mathrm{S}$ - soft nucleophiles to the corresponding oxide products through the insertion of one atom of oxygen into the substrate 4,5 . hFMO3 is responsible for the physiological transformation of trimethylamine (TMA) to trimethylamine $\mathrm{N}$-oxide (TMAO) ${ }^{6}$. Recent works have demonstrated a clear correlation between high levels of TMAO in the body and cardiovascular diseases $7-12$. The new findings place FMO3 in the context of atherosclerosis and cardiovascular disease and efforts are being made to elucidate the regulation and the molecular actors involved in the process ${ }^{13}$. Therefore methods for the assessment of the enzyme function in terms of catalytic activity are strongly needed as well as ways to test the inhibition of the TMAO synthesis reaction. Here we report the first kinetic study of hFMO3 by time-based ITC.

The ITC substrate conversion experiment is carried out using NADPH reduced enzyme in the sample cell. Upon reduction with NADPH the enzyme binds oxygen and can either perform monooxygenation in the presence of a suitable substrate or decay with concurrent production of $\mathrm{H}_{2} \mathrm{O}_{2}{ }^{14}$. The basal uncoupling reaction always occurs, but the ITC system is equilibrated initially with the reduced enzyme, so the $\Delta$ Power $(\Delta \mathrm{P})$ between the cells is maintained throughout the whole experiment and upon substrate addition only product formation, amine oxidation (Scheme1, reaction 3), is actually detected whereas the uncoupling reaction is continuously compensated by the instrument equilibration yielding a flat baseline.

$$
\begin{gathered}
h F M O 3_{O X}+N A D P H \\
\downarrow^{1} \\
h F M O 3_{R E D}+N A D P^{+}+O_{2} \\
\downarrow^{2} \\
h F M O 3_{H_{2} O_{2}}+\mathrm{NADP}^{+}+S \\
\downarrow^{3} \\
\text { hFMO3 }_{O X}+\mathrm{NADP}^{+}+\mathrm{H}_{2} \mathrm{O}+\mathrm{S}-\mathrm{O}
\end{gathered}
$$

Scheme 1 Reactions carried out by hFMO3. 1) hFMO3 oxidizes NADPH, 2) binds oxygen forming hydroperoxyflavin and 3) oxidizes the substrate. The ITC setup measures reaction 3 because hFMO3 is already reduced in the sample cell and immediately binds oxygen.

By operating in kinetics mode, the heat flow variation of time-based ITC can be directly correlated to the rate of the reaction. The data obtained after the measurement are the offset of the heat plot from the starting baseline (Scheme 2 ), and they repre-sent the thermal power ( $\mu \mathrm{cal} / \mathrm{s}$ ) provided by the calorimeter to the sample cell to compensate for the heat change. The thermal power is proportional to the heat flow that is taking place in the sample cell over time ${ }^{15}$. Michaelis-Menten parameters are then derived by using the total molar enthalpy $(\Delta \mathrm{H})$ and the heat flow $(\mathrm{dQ} / \mathrm{dt})$ calculated at several substrate concentrations. In two different experiments, firstly the heat generated from the total conversion of the substrate is measured and secondly the heat production is measured at increasing substrate concentrations using the variation of heat calculated from the first experiment to fit the experimental data (Scheme 2). 




Scheme 2 Principles of time-based ITC for $K_{m}$ and $k_{\text {cat }}$ determination for hFMO3. 1) Reduced enzyme reacts with the substrate 2) Enthalpy of the reaction is determined by single-injection mode and kinetics calculated by multiple-injections mode. 3) Data analysis is performed. $\Delta H$ is enthalpy. $Q$ is heat, $t$ is time, $n$ are moles of product, $V$ is volume, $v$ is reaction rate, $P$ is power, $[P]$ is product concentration

More specifically, the experimental setup for measuring hFMO3 activity is initiated by the injection of the substrate into the sample cell containing the reduced enzyme at a constant temperature. As soon as catalysis occurs, the amount of heat released by the reaction is measured and this value is directly related to the amount of substrate that is transformed into the product. In this work either low/mid or no feedback modes were employed for the measurement of enzyme kinetics: the no feedback mode was used in the first stage of the experimental setup to highlight major differences between full reaction and selected controls. Low/mid feedback mode was then used as the optimal setup for all the reactions that yielded kinetic parameters and when a competing substrate was used. The specific feedback mode can be optimized for each experiment in order to maximize the amplitude of the phenomenon to be observed, but it does not impact the result of the experiment ${ }^{16}$. A typical no feedback mode time-based ITC single injection experiment, in which the instrument does not compensate for the changes in temperature that occur during the experiment, is shown in Figure 1. Under aerobic conditions, hFMO3 oxidizes the substrate as indicated by the presence of a strong negative enthalpic peak when trimethylamine is added in the cell (Fig. 1 filled circles). The exchanged heat, as expected, is stronger in the presence of enzyme NADPH and the substrate as compared to simple enzyme reduction by NADPH. Three different control experiments were performed to prove the loaded gun mechanism. In control 1 the injection of TMA in the cell results in a positive enthalpic contribution due to the dilution of the substrate in the cell which contains only the phosphate buffer and the NADPH cofactor. The plot of the heat change over time shows how, immediately after the maximum of about $0.5 \mu \mathrm{cal} / \mathrm{s}$ is achieved the curve goes back to the original baseline and does not vary anymore (Fig. 1 thick curve).

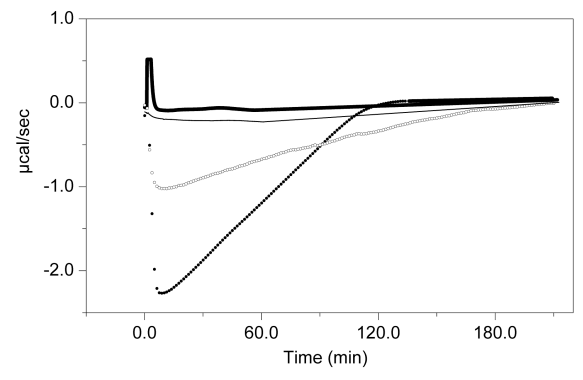

Fig. 1 No feedback mode time-based ITC single injection experiments. NADPH reduced hFMO3 + TMA injection (filled circles). NADPH+TMA injection (thick curve), Buffer + NADPH injection (thin curve), hFMO3 + NADPH injection (empty circles)

In control 2, NADPH is titrated in the cell containing the phosphate buffer. The titration yields a minimal change in the baseline of about $0.2 \mu \mathrm{cal} / \mathrm{s}$ and subsequent stabilization (Fig. 1 thin curve). In control $3 \mathrm{NADPH}$ is titrated in the cell that contains the enzyme and the phosphate buffer (Fig. 1 empty circles). In this case a strong negative peak reaching a minimum of $1.0 \mu \mathrm{cal} / \mathrm{s}$ is detected and a slow return to the original baseline is completed only after 200 minutes. These data are in line with a complete oxidation of the NADPH in the cell and provide the right setup for evaluating the effect of the FMO3 loaded gun on the substrate. Indeed, when the NADPH reduced enzyme in the cell is titrated with benzydamine a positive enthalpic peak is detected (Fig.1 filled circles), due to the heat of dilution of the substrate in the buffer, followed by a strong negative minimum down to a value of about $-2.2 \mu \mathrm{cal} / \mathrm{s}$. During the enzymatic reaction, a faster return to the original baseline is detected. hFMO3 acts as a loaded gun attacking the substrate and accelerating the return to its oxidized state and the release of product and NADP ${ }^{+}$. The results are fully in line with previously published stopped-flow data indicating reduction of the enzyme followed by formation of the hydroperoxy intermediate with rate

$$
\text { iris-AperTO }
$$


acceleration when the substrate is also present ${ }^{14,17-20}$. The total molar enthalpy and the heat flow occurring during the reaction for trimethylamine $\Delta \mathrm{H}$ was found to be $-49.5 \mathrm{kcal} / \mathrm{mol}$. In order to fully understand how responsive the time-based ITC system is to relative changes in enzyme concentration, four different experiments in multiple injections mode were performed with $\mathrm{hFMO} 3$ concentrations in the range 1.2-9.6 $\mu \mathrm{M} \mathrm{hFMO} 3$ (Figure 2).

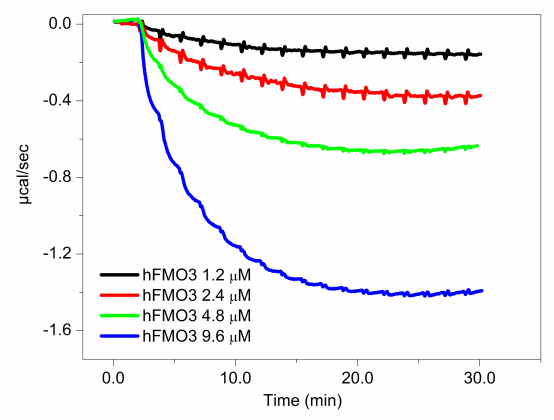

Fig. 2 Multiple injections time-based ITC measurements of TMA $(2 \mu \mathrm{l}$ of $30 \mu \mathrm{M})$ in 50 $\mathrm{mM} \mathrm{KPi}$ buffer $\mathrm{pH} 7.4$ containing $\mathrm{hFMO3}(1.2-9.6 \mu \mathrm{M})$ and $1.2 \mathrm{mM} \mathrm{NADPH}, 25^{\circ} \mathrm{C}, 300$ rpm stirring, mid-feedback mode, 120 seconds spacing between each injection.

The data show how time-based ITC measures variations with respect to the initial baseline values with as little as $1.2 \mu \mathrm{M}$ of hFMO3.Other well-known substrates of hFMO3 such as benzydamine, ethionamide and methimazole were also tested (Figure S1, Figure S2). Also in this case multiple injection mode was employed to reach the maximum enzyme velocity upon subsequent injections without letting the system re-equilibrate back to the original baseline. All the substrates tested showed a typical MichaelisMenten behaviour and no product inhibition was detected. Overall heat change due to product formation was significant for all the substrates studied, leading to a low signal to noise ratio. The results reported in Table 1 are found to be fully in line with previously reported data for other methods ${ }^{21-24}$ except for ethionamide that exhibited a significantly lower $\mathrm{K}_{\mathrm{m}}$ value, but in this specific case the only available reference (Henderson et al., $2008^{24}$ ) data were obtained at the non-physiological of pH 9.5, so they cannot directly comparable to our setup.

Table 1 Michaelis-Menten parameters calculated by time-based ITC

\begin{tabular}{ccccc}
\hline substrate & $\mathrm{K}_{\mathrm{m}} \mu \mathrm{M}$ & $\begin{array}{c}\text { Ref. } \\
\mathrm{K}_{\mathrm{m}} \mu \mathrm{M}\end{array}$ & $\mathrm{k}_{\text {cat }} \min ^{-1}$ & $\begin{array}{c}\text { Ref. } \\
\mathrm{k}_{\text {cat }} \min ^{-1}\end{array}$ \\
\hline trimethylamine & $16.8 \pm 1.2$ & $28.0^{21}$ & $42.0 \pm 5.6$ & $36.3^{21}$ \\
benzydamine & $111.0 \pm 4.6$ & $80.0^{22}$ & $43.0 \pm 6.1$ & $36.0^{22}$ \\
methimazole & $15.9 \pm 1.3$ & $35.0^{23}$ & $23.7 \pm 2.9$ & $50.0^{23}$ \\
ethionamide & $35.0 \pm 2.4$ & $336.0^{24}$ & $13.1 \pm 0.6$ & $58.4^{24}$
\end{tabular}

The $\Delta \mathrm{H}$ is the sum of all heats that are exchanged during the observed reaction and is dependent on the molar enthalpy of all the processes involved and, when existing, upon proton uptake/release from the buffer which normally corresponds to proton acquisition from the buffer solution. The measured $\Delta \mathrm{H}$ can therefore be defined as apparent $\left(\Delta \mathrm{H}_{\text {app }}\right)$, as this includes the intrinsic $\Delta \mathrm{H}_{\text {int }}$ of the reaction, as well as the ionization enthalpy of the buffer $\left(\Delta \mathrm{H}_{\text {ion }}\right)$ for the number of exchanging protons (n) leading to the relationship ${ }^{16}: \Delta \mathrm{H}_{\text {app }}=\Delta \mathrm{H}_{\text {int }}+\mathrm{n} \Delta \mathrm{H}_{\text {ion. }}$. In order to calculate the $\Delta \mathrm{H}_{\text {int }}$ the reduced enzyme was titrated with TMA in 3 different buffers, phosphate, HEPES and TRIS, each with a specific heat of ionization. Data fitting yielded the abstraction of a single proton from the buffer solution and an intrinsic $\Delta \mathrm{H}_{\mathrm{int}}$ of $-31.4 \mathrm{kcal} / \mathrm{mol}$ (Figure 3, S3).

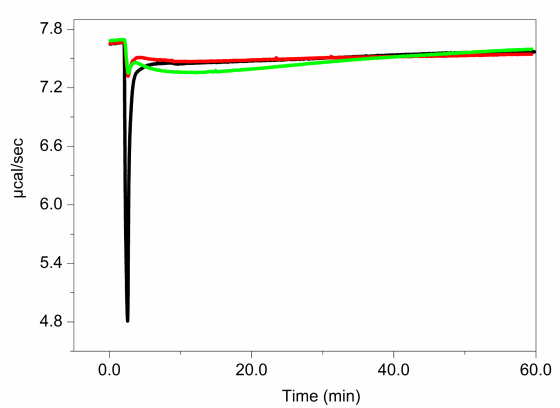

Fig. 3 Determination of the intrinsic $\Delta H$ of the reaction measured by time-based ITC single injection mode. Conditions are 4.8 $\mu \mathrm{M}$ hFMO3, $1.2 \mathrm{mM} \mathrm{NADPH,} 10 \mu \mathrm{M}$ TMA in 20 mM HEPES (black curve), TRIS (red curve) or phosphate (green curve) buffer, $25^{\circ} \mathrm{C}, 300 \mathrm{rpm}$ stirring, low feedback mode, titration volume $2 \mu \mathrm{l}$. 
In the last step of the catalytic cycle of hFMO3 the hydroperoxyflavin FAD-OOH decays performing monooxygenation on the substrate molecule. After monooxygenation the hydroxyflavin FAD-OH is converted back to original oxidized FAD from with subsequent production of $\mathrm{H}_{2} \mathrm{O}$ and release of $\mathrm{NADP}^{+} . \mathrm{H}_{2} \mathrm{O}$ is formed upon proton abstraction from the buffer solution. As there are no data available in literature for this measurement, these data represent the first direct evidence of proton exchange during the enzymatic reaction. FMO is known to work better at $\mathrm{pH}$ above $8.0^{25}$. In order to test the $\mathrm{pH}$ dependent activity for hFMO3 several single injections of TMA were performed in the pH range between 7.0 and 9.0 (Fig. 4). The results clearly show how the enzyme is more active above $\mathrm{pH} 8.0$ as demonstrated by both the increased heat exchanged and the total turnover of the substrate at $\mathrm{pH} 8.4$ compared to $\mathrm{pH} 7$.

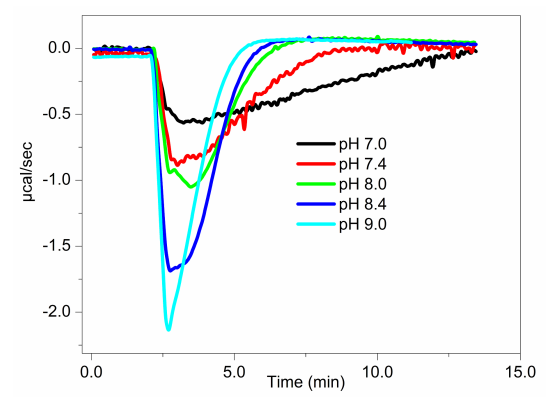

Fig. $4 \mathrm{pH}$ dependence of hFMO3 activity measured by time-based ITC single injection mode. Conditions are $4.8 \mu M$ hFMO3, $1.2 \mathrm{mM}$ NADPH, $10 \mu \mathrm{M}$ TMA in $50 \mathrm{mM}$ TRIS buffer, $25^{\circ} \mathrm{C}, 300$ rpm stirring, low feedback mode, titration volume $2 \mu \mathrm{l}$.

TMAO was recently found as one of the metabolites associated to cardiovascular disease ${ }^{26}$. One of the possible strategies to reduce the body levels of TMAO is to inhibit the FMO3 function. To do so, biochemical methodologies must be developed that address directly the formation of TMAO. Methimazole is a very good competing substrate ${ }^{27}$ for both N- or S- oxidation that is also very often referred to as a competitive inhibitor of the enzyme. We tested the inhibitory effect of methimazole on TMA metabolism using a set of concentrations of methimazole $(0-128 \mu \mathrm{M}$, Figure $5 \mathrm{~A})$.
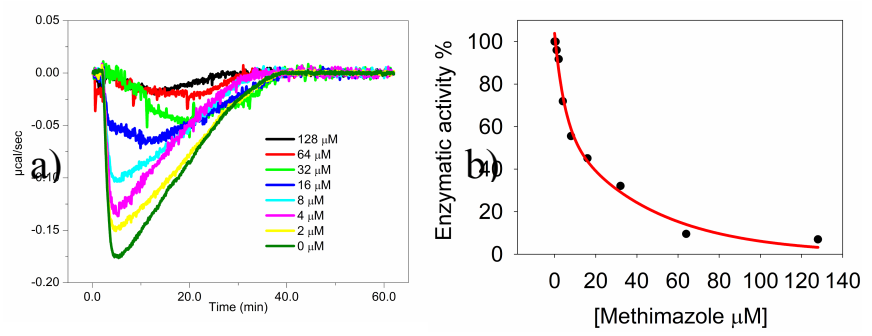

Fig. 5 Inhibition of hFMO3 activity measured by single injection time-based ITC mode. A) Conditions are $4.8 \mu \mathrm{M}$ hFMO3, $1.2 \mathrm{mM}$ NADPH, $30 \mu \mathrm{M}$ TMA, 0-128 $\mu \mathrm{M}$ methimazole in $50 \mathrm{mM}$ phosphate buffer, $\mathrm{pH} 7.425^{\circ} \mathrm{C}, 300 \mathrm{rpm}$ stirring, low feedback mode, titration volume $2 \mu \mathrm{l}$. B) Enthalpy values obtained in the presence of different concentrations of inhibitor were fitted using a sigmoidal function.

When increasing concentration of methimazole are included in the ITC cell and constant concentration of TMA is titrated the negative enthalpic peak decreases indicating that the competing substrate is contrasting the conversion of TMA to TMAO. A plot of the heat as a function of methimazole yields an $\mathrm{IC}_{50}$ concentration $^{28}$ of $12.5 \mu \mathrm{M}$ (Figure $5 \mathrm{~B}$ ).

In conclusion, to date the only direct binding of a ligand to hFMO3 using ITC has been carried out with the oxidized NADP cofactor ${ }^{17}$. Here we show for the first time how time-based ITC can address fundamental enzymology processes by operating in kinetic mode, allowing us to measure transient ligand binding. The method was demostrated for different substrates such as trimethylamine, benzydamine, methimazole and ethionamide. Most interestingly, given the importance of identifying potential inhibitors of TMAO synthesis in humans, we have demonstrated how the action of a known competing substrate of hFMO3, methimazole, can be detected and directly correlated to an $\mathrm{IC}_{50}$ concentration. Upon molecular docking screening and characterization $^{29}$, testing of new inhibitors of hFMO3 can now be envisioned and perhaps a non-substrate molecule that works in kinetics mode could also potentially be tested in classic binding experiments. Finally, the methodology developed in this work can be extended to other enzymes that bear similar mechanisms of action or that normally are difficult to characterize given the transient nature of the binding events occurring between enzyme and substrate or inhibitor.

\section{Conflicts of interest}

There are no conflicts to declare. 


\section{References}

1. J. P. Renaud, C. W. Chung, U. H. Danielson, U. Egner, M. Hennig, R. E. Hubbard and H. Nar, Nat. Rev. Drug Discovery, 2016, 15, 679-698.

2. S. Eswaramoorthy, J. B. Bonanno, S. K. Burley and S. Swaminathan, Proc. Natl. Acad. Sci. U. S. A., 2006, 103, 9832-9837.

3. M. S. Motika, J. Zhang and J. R. Cashman, Expert Opin. Drug Metab. Toxicol., 2007, 3, 831-845.

4. G. Catucci, C. L. Gao, S. J. Sadeghi and G. Gilardi, Rendiconti Lincei-Scienze Fisiche E Naturali, 2017, 28, 195-206.

5. I. R. Phillips and E. A. Shephard, Expert Opin. Drug Metab. Toxicol., 2017, 13, 167-181.

6. D. Fennema, I. R. Phillips and E. A. Shephard, Drug Metab. Dispos., 2016, 44, 1839-1850.

7. J. Miao, A. V. Ling, P. V. Manthena, M. E. Gearing, M. J. Graham, R. M. Crooke, K. J. Croce, R. M. Esquejo, C. B. Clish, D. Vicent, S. B. Biddinger and G. Morbid Obesity Study, Nat. Commun., 2015, 6.

8. M. Warrier, D. M. Shih, A. C. Burrows, D. Ferguson, A. D. Gromovsky, A. L. Brown, S. Marshall, A. McDaniel, R. C. Schugar, Z. Wang, J. Sacks, X. Rong, T. d. A. Vallim, J. Chou, P. T. Ivanova, D. S. Myers, H. A. Brown, R. G. Lee, R. M. Crooke, M. J. Graham, X. Liu, P. Parini, P. Tontonoz, A. J. Lusis, S. L. Hazen, R. E. Temel and J. M. Brown, Cell Rep., 2015, 10, 326-338.

9. M. T. Velasquez, A. Ramezani, A. Manal and D. S. Raj, Toxins, 2016, 8.

10. R. C. Schugar, D. M. Shih, M. Warrier, R. N. Helsley, A. Burrows, D. Ferguson, A. L. Brown, A. D. Gromovsky, M. Heine, A. Chatterjee, L. Li, X. M. S. Li, Z. N. Wang, B. Willard, Y. H. Meng, H. Kim, N. Che, C. Pan, R. G. Lee, R. M. Crooke, M. J. Graham, R. E. Morton, C. D. Langefeld, S. K. Das, L. L. Rudel, N. Zein, A. J. McCullough, S. Dasarathy, W. H. W. Tang, B. O. Erokwu, C. A. Flask, M. Laakso, M. Civelek, S. V. N. Prasad, J. Heeren, A. J. Lusis, S. L. Hazen and J. M. Brown, Cell Rep., 2017, 19, 2451-2461.

11. J. Chhibber-Goel, A. Gaur, V. Singhal, N. Parakh, B. Bhargava and A. Sharma, Expert Rev. Mol. Med., 2016, 18.

12. J. Chhibber-Goel, V. Singhal, N. Parakh, B. Bhargava and A. Sharma, Curr. Med. Chem., 2017, 24, 3942-3953.

13. C. E. Cho and M. A. Caudill, Trends Endocrinol. Metab., 2017, 28, 121-130.

14. L. K. Siddens, S. K. Krueger, M. C. Henderson and D. E. Williams, Biochem. Pharmacol., 2014, 89, 141-147.

15. L. Mazzei, S. Ciurli and B. Zambelli, J. Visualized Exp., 2014.

16. M. J. Todd and J. Gomez, Anal. Biochem., 2001, 296, 179-187.

17. C. L. Gao, G. Catucci, S. Castrignano, G. Gilardi and S. J. Sadeghi, Sci. Rep., $2017,7$.

18. K. C. Jones and D. P. Ballou, J. Biol. Chem., 1986, 261, 2553-2559.

19. X. H. Dai, K. Mashiguchi, Q. G. Chen, H. Kasahara, Y. Kamiya, S. Ojha, J. DuBois, D. Ballou and Y. D. Zhao, J. Biol. Chem., 2013, 288, 1448-1457.

20. N. B. Beaty and D. P. Ballou, J. Biol. Chem., 1981, 256, 4619-4625.

21. D. H. Lang, C. K. Yeung, R. M. Peter, C. Ibarra, R. Gasser, K. Itagaki, R. M. Philpot and A. E. Rettie, Biochem. Pharmacol., 1998, 56, 1005-1012.

22. 22. D. H. Lang and A. E. Rettie, Br. J. Clin. Pharmacol., 2000, 50, 311-314.

23. L. H. Overby, G. C. Carver and R. M. Philpot, Chem.-Biol. Interact., 1997, 106, 29-45.

24. M. C. Henderson, L. K. Siddens, J. T. Morre, S. K. Krueger and D. E. Williams, Toxicol. Appl. Pharmacol., 2008, 233, $420-427$.

25. M. S. Motika, J. Zhang, E. C. Ralph, M. A. Dwyer and J. R. Cashman, Biochem. Pharmacol., 2012, 83, 962-968.

26. Z. Wang, E. Klipfell, B. J. Bennett, R. Koeth, B. S. Levison, B. Dugar, A. E. Feldstein, E. B. Britt, X. Fu, Y.-M. Chung, Y. Wu, P. Schauer, J. D. Smith, H. Allayee, W. H. W. Tang, J. A. DiDonato, A. J. Lusis and S. L. Hazen, Nature, 2011, 472, 57-U82.

27. G. Catucci, I. Polignano, D. Cusumano, C. Medana, G. Gilardi and S. J. Sadeghi, Anal. Biochem., 2017, 522, 46-52.

28. G. A. Holdgate, T. D. Meek and R. L. Grimley, Nat. Rev. Drug Discovery, 2018, 17, 115-132.

29. C. L. Gao, G. Catucci, G. Di Nardo, G. Gilardi and S. J. Sadeghi, Gene, 2016, 593, 91-99. 